\title{
Effectiveness of Settlement of Bad Credit Through Memo Decision on Credit Settlement and Auction at PT Bank BTPN Tbk, Cakranegara Branch
}

\author{
Septiana Hilmi*, Salim HS ${ }^{\text {** }}$, Muhaimin ${ }^{* *}$ \\ * Postgraduate program Legal Study and Notaries, Mataram University, Indonesia \\ *** Lecture of Law Faculty Mataram University, Indonesia
}

\begin{abstract}
This study aims to determine the criteria of bad credit that can be submitted to the settlement through the Credit Settlement Decision Memorandum (MKPK), and Auction at PT. Bank BTPN Tbk, Cakranegara Branch, as well as procedures and obstacles, along with their implementation in the field. This research uses 2 (two) theories, namely effectiveness theory and dispute resolution theory. This research is empirical normative research. Data collection is obtained from the results of interviews, and observations. The conclusion of the results of this study are 1. Settlement of bad loans that can be done with MKPK and auctions are: a. Guaranteed secured features; b. Arrears up to> 180 days; c. Has been issued a warning letter 1-3 (SP1-SP3); d. Has been restructured. 2. The filing procedure for MKPK and auction is almost the same between the two, the difference is for MKPK the initiative to propose the arrival of the debtor, by attaching a request letter from the debtor, while the auction initiative comes from the creditor/bank. 3. Implementation of MKPK and auction at Cakranegara Branch BTPN, more dominantly conducted by auction, $61.70 \%$ auction bidding ratio of total bad loans, with the ratio successfully executed as much as $6.89 \%$. Whereas the settlement with MKPK either with MKPK partially or with MKPK at once, submission of $38.29 \%$ with a success ratio of $66.66 \%$.
\end{abstract}

Keywords: settlement of bad credit, memo of credit settlement decision, auction

\section{Introduction}

Banking institutions have a mission and function in the life of the national economy, one of which is an agent of development, namely as an institution that aims to support the implementation of national development, including regional development, not carrying out the mission of building a group, especially individuals. ${ }^{1}$ In the provisions of Article 6 paragraph (2) of Law Number 10 of 1998 concerning Amendments to Law Number 7 of 1992 concerning Banking, it is explained that banks are business entities that collect funds from the public in the form of deposits and distribute them to the public in the form of credit and / or other forms in order to improve the lives of many people.

Definition of Credit is the ability to carry out a purchase or make a loan with a promise, payment will be carried out at the agreed time period. ${ }^{2}$ An agreement is an event where a person promises to another person or where two people promise each other to do something. From this event, a relationship arose between the two people called the engagement. The agreement issued an agreement between the two people who made it. In its form, the agreement is in the form of a series of words containing promises or abilities that are spoken or written. ${ }^{3}$

Banks as distributors and providers of credit funds for the community do not always run smoothly, sometimes the debtor does not fulfill its obligations according to the agreed time (default).

\footnotetext{
${ }^{1}$ Gazali, Djoni S dan Rachmadi Usman, Hukum Perbankan, (Jakarta: Sinar Grafika, 2010). p. 141

2 Astiko, Manajemen Perkreditan ( Yogyakarta: andi Offset, 1996 ), p. 5

${ }^{3}$ Prof. R. Subekti, S.H., Hukum Perjanjian, (Jakarta: Citra Aditya Bhakti, 1987), $4^{\text {th }}$ Printing, p. 6
} 
Default is considered as a failure to carry out agreed agreements because the debtor does not carry out obligations without reasons that can be accepted by law. In the event of default, creditors can demand compensation and cancellation. Compensation provisions governing engagements to provide something, as stated in Article 1236 of the Civil Code: ${ }^{4}$ "The debtor must replace the costs, losses and interest to the creditor if he makes himself unable to surrender the item or does not treat it as well as possible to save him". Rolling G. Thomas, argues that credit trust or credit by the creditor, is based on the ability of the debtor in terms of returning the loan and interest, and certain according to the estimated credit analysis. Rolling G. Thomas, argues that credit trust or credit by the creditor, is based on the ability of the debtor in terms of returning the loan and interest, and according to the estimated credit analysis. ${ }^{5}$

Based on the decision letter of the Board of Directors of Bank Indonesia Number 31/147 / KEP / DIR, credit is differentiated again into a performing loan and non-performing loan. Credit is said to be no problem if it is included in the current group, while it is said to be problematic if it is included in the classification of substandard, doubtful and loss. ${ }^{6}$ PT. Bank Tabungan Pensiunan Nasional Tbk (BTPN), as one of the private banks engaged in the micro sector, until June 2018 microcredit disbursed funds amounting to Rp 4.08 trillion, down $38 \%$ yoy. While the ratio of non-performing loans (NPL) in this sector is also the highest, namely 3.6\%. ${ }^{7}$ And for BTPN Branch Cakranegara in December 2018 the NPL is quite high at $3.9 \%$ and WO $4 \%$. The solution to the settlement of bad loans is by using the Credit Settlement Decision (MKPK) media and auction media. The many settlement processes submitted by the auction are not in line with the results of the execution in the field, because there are several obstacles, both from internal and external factors.

The method used in this study is empirical normative in this study the meaning is that in analyzing the problem carried out by integrating legal materials, (which is secondary data) with primary data obtained in the field. To determine the sample the author uses the Probability sampling sampling method. Regarding random sampling as stated by Suharsimi Arikunto that: for mere estimation, if the subject is less than $(<100)$ people, then all or at least $>35 \%$ may be taken, but if the subject is more than $(>100)$ people can take $10 \%-15 \%$ or $20 \%-25 \% .^{8}$

\section{Result And Discussion}

2.1 Bad credit that can be submitted to the settlement through memo of credit settlement and auction decisions at PT. Bank BTPN Tbk, Cakranegara Branch

\subsubsection{Loan products from BTPN Tbk, and submission requirements}

Product is something that can be offered to the market to be noticed, used, owned, or consumed so that it can satisfy desires or needs. ${ }^{9}$

The loan product currently offered by Bank BTPN Tbk, is the Installment Term Loan, which is a loan with fixed installments covering principal and interest where installments are paid for a certain period up to a certain period of time, as agreed. This Installment Loan Credit is divided into 3 (three) products, namely: ${ }^{10}$

a. Premium Mapan Products (Ceiling 50 million - 100 million)

b. Established Products (Ceiling> 100 million - 500 million)

c. Medium-Term Products (Ceiling> 500 million - 2 billion)

Submission Terms:

a. Business $>2$ years

b. Mandatory Documents (husband / wife ID, KK, NPWP, SIUP / TDP)

\footnotetext{
${ }^{4}$ Prof. R. Subekti, S.H., \& R. Tjitrosudibio, Kitab Undang-Undang Hukum Perdata, (Jakarta: Balai Pustaka, 2009). p. 224

${ }^{5}$ Hadiwijaya, Rivai Wirasasmita, Analisis Kredit, (Bandung: CV. Pionir Jaya, 2000), p. 6.

${ }_{7}^{6}$ Badriyah Harun, Penyelesaian Sengketa Kredit Bermasalah, (Yogyakarta: Pustaka Yustitia, 2010), Mold 1, p. 114

${ }^{7}$ Galvan Yudistira, Ada perubahan fokus bisnis, penyaluran kredit mikro beberapa bank turun di semester I, http://www.kontan.co.id, posted on July 29, 2018

${ }^{8}$ Suharsini Arikunto, Prosedur Penelitian Suatu Pendekatan Praktis, Revisision IV edition (Jakarta: Rineka Cipta, 2006) p. 134

${ }^{9}$ M. Tohar, Membuka Usaha Kecil, ( Yogyakarta: Kanisius, 2000), p. 83.

${ }^{10}$ The results of interviews with employees of PT. Bank BTPN Tbk., BM Branch Cakranegara, dated March 20, 2019.
} 
c. Photocopy of guarantee and original UN

\subsubsection{Credit process}

A credit agreement is a principal (principal) agreement that is real. As a principle agreement, the guarantee agreement is the assessor. The existence and expiration of the guarantee agreement depends on the principal agreement. Real meaning is that the credit agreement is determined by the transfer of money by the bank to debtor customers. ${ }^{11}$

New debtor candidates who want to get a loan will go through several processes:

a. The initial selection of prospective debtors is carried out by marketing / Relationship Officer (RO);

b. The prospective debtor completes and completes and signs the loan application and the prospective debtor submits the completeness of his mandatory;

c. Relationship Officer (RO) will verify the field (reputation, business presence, ability to pay, and guarantees);

d. The Credit Officer (CO) will review and will provide recommendations / no credit for the proposed;

e. Input decisions on AGAPE;

f. Relationship Officer (RO) will inform the prospective debtor and make an appointment for credit binding;

g. Open a savings account;

h. A Credit Admin (CA) will prepare a memo for disbursement and a credit agreement letter (SPK);

i. The Credit Admin (CA) will send a withdrawal memo to the head office admin to make a loan account;

j. Debtor, Credit Admin (CA) and Branch Manager will sign a credit agreement letter (SPK);

k. The Operational Officer (OO) will open unblock debtor accounts.

1. A Credit Admin (CA) will file a debtor disbursement document.

\subsubsection{Credit Quality Determination (Collectibility)}

The determination of credit quality in principle follows the Financial Services Authority Regulation Number 11 / POJK.03 / 2015 concerning Provisions on Prudence in the National Economic Stimulus Framework for Commercial Banks, which is based on the stipulation of payment of principal and/or interest. Debtors can be classified as current debtors, troubled debtors (SM), bad debtors (NPLs).

Determination of collectability 1 (one) up to 5 (five) based on delinquent days follows the following table: ${ }^{12}$

Table 1. Determination of collectability

\begin{tabular}{|l|c|}
\hline \multicolumn{1}{|c|}{ Collectability } & Arrears Day \\
\hline 1. Smooth & 0 \\
\hline 2. In Special Attention & $1-90$ \\
\hline 2. Substandard & $91-120$ \\
\hline 3. Doubtful & $121-180$ \\
\hline 4. Traffic & $>180$ \\
\hline
\end{tabular}

\subsubsection{Causes of Bad Credit at Bank BTPN Tbk, Cakranegara Branch}

According to Zainal Asikin, the causes of bad credit are as follows: ${ }^{13}$

a. Self-Dealing;

b. Anxiety for Income;

c. Compromise of Credit Principles;

d. Incomplete Credit Information;

e. Failure to Obtain or Enforce Liquidation Agreements;

f. Complacency;

\footnotetext{
${ }^{11}$ Hermansah, Hukum Perbankan Nasional Indonesia, (Jakarta: Kencana Prenada Media Group, 2005), p. 71

${ }^{12}$ The results of interviews with employees of PT. Bank BTPN Tbk., ACM Area Mataram, April 30, 2019

${ }^{13}$ Zainal Asikin, Pengantar Hukum Perbankan Indonesia, ( Jakarta: RajaGrafindo Persada, 2015), p. 194
} 


\section{g. Lack of Supervising; \\ h. Technical Incompetence; \\ i. Poor Selection of Risks; \\ j. Overlending; \\ k. Competition;}

Based on the results of the data and interviews with the Branch Manager of BTPN Bank Branch Cakranegara (interview conducted on March 20, 2019), the causes of bad debtors consist of 2 (two) factors, namely, internal factors and external factors.

a. Internal factors that cause the occurrence of bad credit, namely:

1) Deviations in the implementation of credit procedures. Bank employees / officers do not carry out the rules according to SOP / operational standards. Not all bank employees work professionally. Proximity and service from customers sometimes affects the decision of the loan officer so that it does not work properly;

2) Weak information about bad credit in the marketing area;

3) Weak credit supervision;

4) Coaching creditors to customers is still lacking;

5) Competition between banks;

6) Banks are too chasing targets;

b. External factors that are the cause of the occurrence of bad credit, namely:

1) The business of the debtor failed / went bankrupt

The business of the debtor failed due to several factors, namely:

a) Over Finance

b) Uncollectible receivables

c) Business competition

d) Deceived

e) Family problems

The failed/bankrupt debtor's business causes are mainly due to poor management and the magnitude of debtor's dependence on loans.

2) Use of Credit Not in Accordance with the Purpose of Use

A number of loans given for the purpose of business capital or business development are misused by the debtor, for example, the submission of business capital, but the implementation for consumptive purchases, disbursed loans are not used as the purpose of the gift the use of deviant credit), so that capital moves only amounting to initial capital, so businesses do not develop while credit payments increase.

3) High credit interest rates

4) Debtors have bad intentions

Debtors intentionally and with all efforts to get credit, either by providing incorrect information and data. And the debtor cannot be held accountable for his debt.

5) The debtor runs away

Most of the debtors who fled were debtors who were not native of the region. Even if the native debtor is from the area, the debtor runs away to become TKI abroad.

6) Force Majeur

7) The existence of fire and natural disasters such as flash floods and earthquakes, which resulted in all banks issued a memo to extend the loan period for debtors who get natural disaster. With no installments for several months.

\subsubsection{Handling of Bad Credit at Bank BTPN Tbk, Cakranegara Branch}

Debtor handling matrix according to debtor's Ability \& Will: 


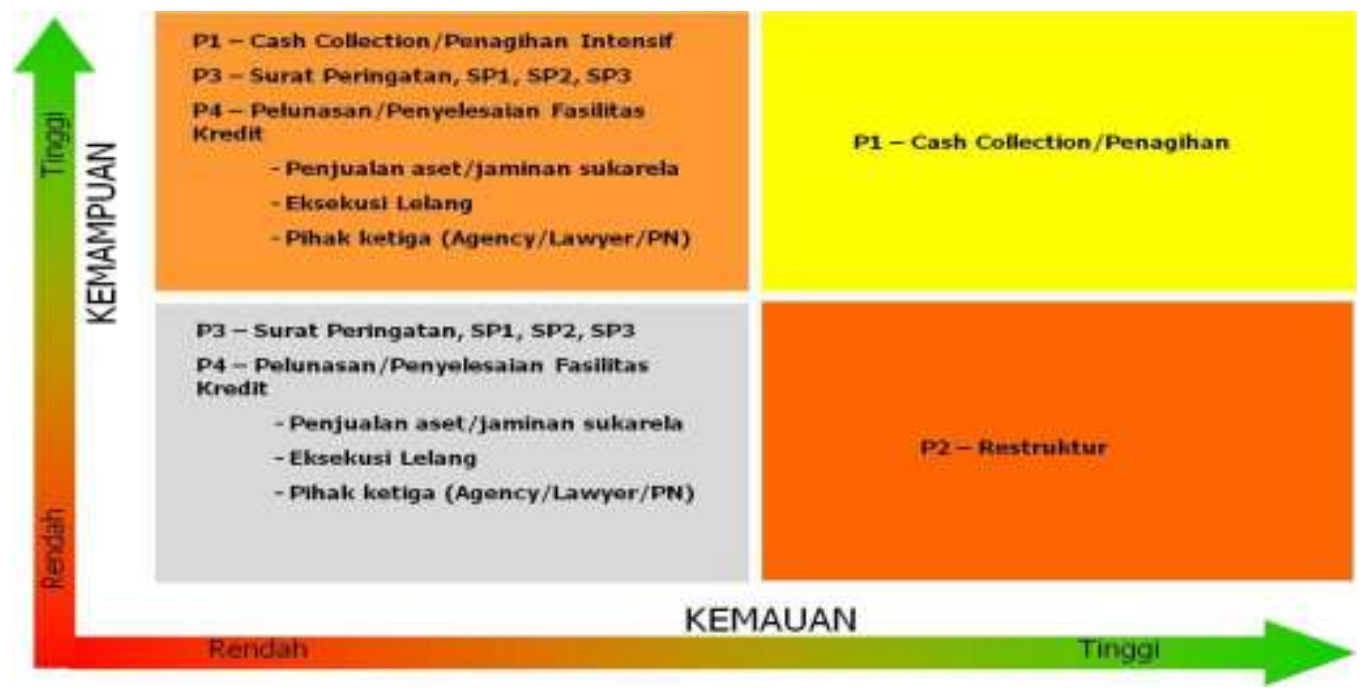

Figure 1. Handling of Bad Credit

\subsubsection{Terms of Submission of Memo for Credit Settlement and Auction Decision at BTPN Tbk. Cakranegara Branch}

Administrative requirements for submitting credit settlement decision memos (MKPK) and auctions are:Copy SP 1 - SP 3 berikut tanda terima nya (wajib ada);

a. Memo Review

b. LV Bankrupt

c. MLK-PPA

d. Previous LVPA

e. Copy of Initial MKK (plus Top Up MKK if available);

f. Initial LVPJ copy;

g. Copy of Initial Credit Agreement (plus Add PK Top Up if any);

h. Copy of MKRK (if any);

i. Copy of LVPJ Restructuring (if any);

j. Copy of Addendum for Restructured PK (if any);

k. Copy of SKMHT and APHT;

1. Copy of SHT, copy of SHM, copy of SPPT PBB (required);

m. Copy of IMB (if any);

n. Current guarantee photo. (front view, side view, visible inside, road access and environment around the guarantee;

o. Result of Assessment of Public Appraisal Services Consultant (KJPP) / independent Appraisal for collateral value above Rp. 1 billion.

2.2 The procedure for submitting memo on credit and auction settlement decisions and the obstacles to resolving bad credit at PT. Bank BTPN Tbk, Cakranegara Branch

\subsubsection{Stages in Submission of Credit Settlement Decision Memo}

The stages in submitting a credit settlement decision memo (MKPK) are as follows:

a. The first stage

Branches get a list of debtors who submit a request for a credit settlement decision memo, then the branch reviews the application for the credit settlement decision (MKPK) memo.

b. Second stage

The credit team or also called the credit officer $(\mathrm{CO})$ conducts a survey on the location of the debtor's business, by carrying out the old debtor documents. After the credit officer (CO) verifies, the credit officer $(\mathrm{CO})$ will provide the results of the debtor's verification to credit admin $(\mathrm{CA})$.

c. Third stage

The Admin Credit (CA) will make a credit settlement decision memo (MKPK) based on the results of the credit officer $(\mathrm{CO})$ verification and will be signed by the credit officer $(\mathrm{CO})$ if the contents are correct, then signed by the Branch Manager (BM). 
d. Fourth stage

The branch sends a credit settlement decision (MKPK) to the area for approval of the area credit officer (ACO) and Area Business Leader (ABL). Then sent to Region, DH and Head Office / according to BWMK.

e. The fifth stage

If the document is sent complete, the Head Office will immediately review, if the document is incomplete, it will be returned to the branch. If filing a credit settlement decision (MKPK) is approved by the Head Office, the branch must immediately inform the debtor.

f. The fifth stage

The debtor must be able to complete the payment according to the application stated in the credit settlement decision memo (MKPK) no later than 30 (thirty) days after the credit settlement decision memo (MKPK) is signed by the Head Office, if the period given cannot be resolved, then the debtor must submit again, according to the initial procedure.

\subsubsection{Stages in Submission of Auction}

There are auction stages as follows: ${ }^{14}$

1. The first stage

Branch/Area/Region submits auction limits to the Head Office MUR Asset Management Team with a SLA (Service Level Agreement) maximum of 2 (two) days.

2. Second stage

After the document is complete and correct, the Branch makes 4 documents for Limit Submission and Auction Fees to the Head Office which consists of:

a. Application for Auction;

b. Auction Fee Approval Memo;

c. Auction Limit Memo;

d. Attachment to the Auction Guarantee Value.

3. Third stage

Make an Application for Bidding Registration to KPKNL

4. Fourth stage

Registered with KPKNL

5. The fifth stage

a. The branch is required to make a notification letter for the schedule of advance (SPPJ) Auction that must be submitted and explained to the Debtor and the collateral occupants, to minimize the debtor's claim as well as step pressure for the debtor;

b. There must be a receipt/receipt of receipt as proof to the KPKNL that the implementation of the Auction has been known by the Debtor;

c. Branches make leaflets First Announcement Announcements that must be posted on the collateral location and strategic locations around the guarantee. For example, on the notice board of the Village office, the sub-district office with the permission of the relevant party (example attached);

d. Make the SPM for auction fees in accordance with the Memo for Bid Fees that have been approved by KP officials to pay related fees (independent appraisal fees, newspaper advertising fees, SKT fees etc.);

e. In the implementation of the auction, the seller must precede the announcement of the auction.

6. Sixth stage

Auction implementation;

\subsubsection{Obstacles in the implementation of Memo for Credit Settlement and Auction Resolutions}

In the implementation of the credit settlement decision memo (MKPK), not only can it run smoothly, but the obstacles of various factors are:

1. Internal factors

${ }^{14}$ The results of interviews with employees of PT. Bank BTPN Tbk., ARM Area Mataram, March 12, 2019 
The authority possessed by each official is different, so for the process of submitting approval for a credit settlement decision memo (MKPK), it will take 3-7 days for the approval process to be in accordance with the BWMK.

2. External factors

a. The debtor does not have money / funds at the time the approval of the credit settlement decision memo (MKPK) is approved;

\begin{tabular}{|l|l|l|l|l|l|l|l|l|l|l|l|l|l|l|}
\hline \multirow{2}{*}{ Description } & \multicolumn{10}{|c|}{2018} \\
\cline { 2 - 10 } & Jan & Fe & Ma & Ap & Ma & Jun & Jul & Augu & Sep & Oc & No & De & Tota & $\%$ \\
\hline
\end{tabular}

b. The debtor's fund when memo the credit settlement decision (MKPK) is approved is not appropriate or less than the submission;

While the obstacles in conducting the auction are influenced by several factors, namely:

1. Internal factors

a. The length of the review process at KPKNL is because the review staff is limited, and the number of banks and state and private agencies that submit an auction, so that the file that goes to KPKNL overload.

b. Time, the process of submission in the branch to the stage of submission to KPKNL, announcements in the media up to the implementation of the auction date, takes approximately 30-45 days.

2. External factors

a. The intention of the debtor is not good, so he does not want to give up his guarantee, the debtor tends to resist;

b. Community culture;

c. Lack of public interest in goods sold.

d. The number of brokers for strategic guarantees.

2.3 Memo Implementation of Credit Settlement and Auction Decision on Settlement of Bad Credit at PT. Bank BTPN Tbk, Cakranegara Branch

BTPN Tbk Bank. Cakranegara branch in December 2018 has an Outstanding of 18 Billion with total debtors of 107 NOA from January to December 2018. Year-end NPL is 3.9\% with total inventory of debtors jammed from all products including old products namely free products and flexion products of 9.7 billion with 60 NOA. Whereas bad loans from Mapan's products amounted to 8.9 billion from the total Outstanding of 12.4 billion with 47 Noa, the process of which was mostly carried out by auction.

Table 2. Details of Settlement of bad loans through MKPK and Auctions 


\begin{tabular}{|l|l|l|l|l|l|l|l|l|l|l|l|l|l|l|}
\hline & & $\mathrm{b}$ & $\mathrm{r}$ & $\mathrm{r}$ & $\mathrm{y}$ & $\mathrm{e}$ & $\mathrm{y}$ & $\mathrm{st}$ & $\mathrm{t}$ & $\mathrm{t}$ & $\mathrm{v}$ & $\mathrm{c}$ & $\mathrm{l}$ & \\
\hline Loss Debtor & 10 & 2 & 3 & 2 & 4 & 4 & 4 & 2 & 3 & 4 & 3 & 6 & 47 & - \\
\hline $\begin{array}{l}\text { Submission } \\
\text { of MKPK }\end{array}$ & 4 & 2 & 3 & 1 & 0 & 2 & 1 & 1 & 1 & 2 & 0 & 1 & 18 & $\begin{array}{l}38,2 \\
\text { Realization }\end{array}$ \\
\hline $\begin{array}{l}\text { Submission } \\
\text { of Auction }\end{array}$ & 4 & 1 & 2 & 1 & 2 & 1 & 0 & 1 & 0 & 1 & 0 & 1 & 12 & 6 \\
\hline Realization & 0 & 0 & 1 & 0 & 0 & 0 & 1 & 0 & 0 & 0 & 0 & 0 & 2 & 6,89 \\
\hline
\end{tabular}

Source. DSBI Portal Cakranegara Branch

If seen from the data above, the percentage from January to December can be concluded that the settlement process uses more auction media than the credit settlement decision memo (MKPK), because the credit settlement decision (MKPK) initiative comes from the debtor, while the auction came from creditors / banks, so that the execution MKPK could be greater than the auction. The cause of the small percentage of the rate of success of the auction is the biggest factor is the external factor of the auction. So that the bank as creditor should provide detailed explanations to the debtor since the issuance of a warning letter 1 (first) regarding MKPK, not only dominant with the completion of the auction, which in the end not much can be executed.

Based on the results of visits to debtors with a sample of 20 Debtors, most of the filing ratios by auction were $61.70 \%$ of the total non-performing loans of 47 Debtors, with the ratio successfully executed as much as $6.89 \%$. While the settlement is with the credit settlement decision memo (MKPK), either with MKPK in part or with MKPK at the same time, submission of $38.29 \%$ with a success ratio of $66.66 \%$, much higher than the auction process.

\section{Conclusion}

Based on the results of research and analysis of the Interview and data methods, conclusions can be drawn as follows:

1. Settlement of bad loans that can be done by memo of credit settlement decisions (MKPK) and auctions are:

a. Secured debtors;

b. Arrears up to> 180 days;

c. Warning letter 1 to warning letter 3 (SP1-SP3) has been given;

d. A restructuring has been carried out.

2. The procedure for submitting credit settlement decision memos (MKPK) and auctions is almost the same between the two, the difference is that MKPK initiates the arrival of debtors, by attaching a letter of application from the debtor, while the auction comes from the creditor/bank.

3. Implementation of credit settlement decision (MKPK) memo and auction at Cakranegara Branch BTPN, more dominantly conducted by auction, $61.70 \%$ auction filing ratio of 47 non-performing loans, with the ratio successfully executed as much as $6.89 \%$. While the settlement is with the credit settlement decision memo (MKPK), either with MKPK in part or with MKPK at the same time, submission of $38.29 \%$ with a success ratio of $66.66 \%$, much higher than the auction process. Due to external factors, it can be concluded that the credit settlement decision letter (MKPK) should be informed in detail by the debtor so that the debtor understands the advantages of MKPK and the shortcomings of the auction so that the settlement of the bad debtor can be resolved faster, without having to go through an auction process. This means that the auction process is not effective for resolving bad debtors, only it can help provide shock therapy to the debtor. 


\section{Recommendation}

The following suggestions are expected to be able to provide benefits in the future for PT. BTPN Bank Cakranegara Branch, are as follows:

1. Relationship to debtors is increased, direct visits by officers with intense communication about businesses, and sharing information about new businesses, not just by coming up with cash pickups.

2. Identify early on the debtors who have substandard rhythms, maintenance, make PICs to monitor debtors, and explain in detail and detail when seeing debtors have begun to have problems with restructuring, MKPK and auctions, strengths and weaknesses without being covered .

3. Improve the ability/skills of bank officers, both credit teams, collections and marketing with quarterly assessments so that the knowledge is still being upgraded, so as to reduce the high level of bad debtors caused by internal factors.

\section{References}

\section{Books}

[1] Astiko. 1996. Manajemen Perkreditan. Andi Offset, Yogyakarta

[2] Badriyah Harun. 2010. Penyelesaian Sengketa Kredit Bermasalah. Mold 1. Pustaka Yustitia, Yogyakarta.

[3] Gazali, Djoni S. and Rachmadi Usman. 2010. Hukum Perbankan. Sinar Grafika, Jakarta

[4] Hermansah. 2005. Hukum Perbankan Nasional Indonesia, Kencana Prenada Media Group, Jakarta.

[5] Hadiwijaya, Rivai Wirasasmita. 2000. Analisis Kredit. CV. Pionir Jaya, Bandung

[6] M. Tohar. 2000. Membuka Usaha Kecil. Kanisius, Yogyakarta.

[7] Prof. R. Subekti, S.H. 1987. Hukum Perjanjian. 4th Printing. Citra Aditya Bhakti, Jakarta

[8] Prof. R. Subekti, S.H., \& R. Tjitrosudibio. 2009. Kitab Undang-Undang Hukum Perdata. Balai Pustaka, Jakarta.

[9] Suharsini Arikunto. 2006. Prosedur Penelitian Suatu Pendekatan Praktis. Revision VI edition. Rineka Cipta, Jakarta.

[10] Zainal Asikin. 2015. Pengantar Hukum Perbankan Indonesia. RajaGrafindo Persada, Jakarta.

\section{Regulations}

[1] Law Number 10 of 1998 concerning Banking, LNRI Th. 1998 NO. 182, TLN N0. 3790.

[2] Law Number 7 of 1992 concerning Banking, LNRI Th. 1992 N0. 31, TLN N0. 3472.

[3] Financial Services Authority Regulation Number 42/POJK.03/2017 concerning Obligations for Preparing and Implementing Credit Policy or Bank Financing for Commercial Banks.

[4] Financial Services Authority Regulation Number. 11/POJK.03/2015 concerning Provisions on Prudence in the National Economic Stimulus Framework for Commercial Banks, second part, article 7.

\section{Interview}

[1] Interview with employees of PT. Bank BTPN Tbk., ACM Area Mataram, on April 30, 2019 at the Mataram Area BTPN office.

[2] Interview with employees of PT. Bank BTPN Tbk., ARM Area Mataram, on March 12, 2019 at the Mataram Area BTPN office.

[3] Interview with employees of PT. Bank BTPN Tbk., BM Branch Cakranegara, dated March 20, 2019, at the BTPN office in Cakranegara Branch. 